\title{
Fostering the Development of Written Argumentative Competence in ELT from a Critical Literacy Approach
}

Promoción del desarrollo de la competencia argumentativa escrita en ELT desde un enfoque de alfabetización crítica

Promoção do desenvolvimento da competência argumentativa na escrita no ELI desde uma abordagem de alfabetização crítica

\section{Diego Sánchez-Peña* (iD) orcid org/0000-0002-2422-7192}

\section{Claudia Marcela Chapetón ** (D) orcidorg/0000-0002-7516-1082}

\footnotetext{
Artículo de investigación

Revista Colombiana de Educación, N. 75. Segundo semestre de 2018, Bogotá, Colombia.

doi: 10.17227/rce.num75-8107

Para citar este artículo: Sánchez-Peña, D. y Chapetón, M. (2018). Fostering the Development of Written Argumentative Competence in ELT from a Critical Literacy Approach. Revista Colombiana de Educación, 75, 159-183.
}

(c) PY $_{\mathbf{N C}} \quad \begin{array}{r}\text { Recibido: } 01 / 16 / 2018 \\ \text { Evaluado: 14/04/2018 }\end{array}$

* $\quad$ Magister en Enseñanza de Lenguas Extranjeras. Profesor investigador Departamento de Lenguas, Facultad de Humanidades, Universidad Pedagógica Nacional, Bogotá, Colombia. Correo electrónico: dcsanchezp(apedagogica.edu.co

** Doctora en Lingüística Aplicada de la Universidad de Barcelona. Profesora investigadora Departamento de Lenguas, Facultad de Humanidades, Universidad Pedagógica Nacional. Bogotá, Colombia. Correo electrónico: cchapeton@apedagogica.edu.co 


\begin{abstract}
This article reports the findings of an action research which aimed at describing and analyzing the impact that the implementation of argumentative writing activities through a critical literacy approach may have on $4^{\text {th }}$ semester pre-service teachers ${ }^{\prime}$ argumentative competence development. Participants belong to the B.A. program in English and Spanish teaching at Universidad Pedagógica Nacional. The article draws on qualitative data collection techniques such as questionnaires, focus groups, audio recordings of class sessions, and class artifacts. Findings indicate that adopting a critical literacy approach helped pre-service-teachers foster the development of their written argumentative competence. It was revealed that participants grew as argumentative writers as they were able to take a clear position and weigh their claims. Moreover, they were engaged in reflection that fostered awareness of their roles as future ELT educators which in turn empowered them to discover teaching as a tool for transformation.
\end{abstract}

\section{Keywords}

argumentative competence argumentative essay writing; critical literacy; ELT

\title{
Resumen
}

\section{Palabras clave}

competencia argumentativa; redacción de textos argumentativos; la alfabetización crítica; ELT
Este artículo da cuenta de los resultados de una investigación de acción, que tuvo como objetivo describir y analizar el posible impacto de la implementación de las actividades de escritura argumentativa a través de un enfoque de alfabetización crítica sobre el desarrollo de competencia argumentativa de los maestros en formación de $4^{\circ}$ semestre Los participantes hacen parte de la Licenciatura en Enseñanza de inglés y español de la Universidad Pedagógica Nacional. El artículo se basa en técnicas de recopilación de datos cualitativos, como cuestionarios, grupos focales, grabaciones de audio de sesiones de clase y artefactos de clase. Los resultados indican que la adopción de un enfoque de alfabetización crítica ayudó a los profesores en formación a fomentar el desarrollo de su competencia argumentativa escrita. Se reveló que los participantes crecieron como escritores argumentativos, ya que fueron capaces de tomar una posición clara y sopesar sus afirmaciones. Adicionalmente, hicieron una reflexión que fomentó la conciencia de sus roles como futuros educadores de ELT, lo que a su vez los capacitó para descubrir la enseñanza como una herramienta para la transformación.

\section{Resumo}

Este artigo dá conta dos resultados de uma pesquisa de ação, que visou descrever e analisar o possível impacto da implementação das atividades de escrita argumentativa através de uma abordagem de alfabetização crítica sobre o desenvolvimento da competência argumentativa dos professores em formação de quarto semestre. Os participantes são parte da Licenciatura em Ensino de Inglês e Espanhol da Universidade Pedagógica Nacional. O artigo baseia-se em técnicas de coleta de dados qualitativos, como questionários, grupos focais, gravações de áudio de sessões de aula e artefactos de aula. Os resultados assinalam que a adoção de um escopo de alfabetização crítica foi útil para os professores em formação melhorarem o desenvolvimento de sua competência argumentativa na escrita. Revelou-se que os estudantes cresceram como escritores argumentativos, pois foram capazes de assumir uma posição clara e sopesar suas afirmações. Adicionalmente, refletiram sobre suas funções como futuros professores de inglês, capacitando-se, ao mesmo tempo, para descobrir o ensino como uma ferramenta para a transformação.

\section{Palavras-chave}

competência argumentativa; redação de textos argumentativos; alfabetização crítica; EL 


\section{Introduction}

Argumentative competence is a central component of academic and social life. Developing argumentative competence is a requirement for democratic participation and for advocating one's civil rights in society. This competence is a tool to take a stand, to assess truth, to identify fallacies or weak arguments, to defend one's ideas and to engage in dialogue where one's views and others' are interpreted and evaluated in order to provide rebuttals or counter arguments to opposing views. Therefore, developing written argumentative competence implies an intellectual contact or dialogue between writers and readers in which different perspectives are considered, examined, evaluated, and rebutted.

As stated by Augustiniene and Čiučiulkienè (2012) the competencies of argumentation play a relevant role in the preparation of students' long life learning since these competencies are necessary both to understand and participate in the different spheres of educational discourse. However, as these authors point out, teachers often assume that students know how to defend their ideas in a reasoned way, while most students lack argumentation foundations; therefore, many of them face difficulties or feel disappointment when defending their views in public.

Argumentation and argumentative competence in EFL have been approached mainly from a linguistic or functional perspective when it comes to writing argumentative texts or defending one's ideas in a reasonable way. Here is the relevance of this research study, which aims to integrate the development of written argumentative competence into a foreign language teacher training program through a critical literacy approach. This critical perspective engages students in readings of their world in a critical way, to question their reality, to reflect upon problems significant to their lives, to propose solutions to those problems, and to act upon reality in order to transform it. Thus, this qualitative action research attempted to develop the written argumentative competence of a group of pre-service teachers from a critical literacy approach and aimed at answering the following research question: What impact may the implementation of argumentative writing activities have on the development of argumentative competence in $4^{\text {th }}$ semester pre-service teachers through a critical literacy approach? 


\section{Theoretical Foundations}

\section{Critical literacy as an approach to foster empowerment}

Shor (1999) states that critical literacy is language use that questions the social construction of the self. Thus, a critically literate person is able to examine his/her ongoing development, to reveal subjective positions from which each person makes sense of the world and acts on it. According to Giroux (1987), in its more radical, sense critical literacy means to make one's self present as part of a political project in which the production of meaning, the possibility for human agency, democratic community, and transformative social action are linked.

One of the aims of critical literacy is to empower the students in all aspects of their lives. Green (2001) highlights that literacy means empowering only when it turns people into active questioners of the social reality around them. Regarding this, Coffey (2010) proposes that students should produce counter-texts, which involve having students generate texts from a non-main stream perspective. This author also suggests offering students occasions to speak from the point of view of those voices that are often silenced or marginalized, thereby empowering them.

Coffey (2010) underscores the importance of providing opportunities for students' choice as an effective way to involve, encourage, and empower students to actively participate in the construction of knowledge. To illustrate this, choosing a topic for inquiry is not considered critical unless students evaluate the problems involved in society and how the conditions of society create this problem. Likewise, McLaughling and Devoogd (2004) claim that, in reading, the emphasis has traditionally been on the author's power, but in critical literacy readers are text critics who actively exercise their power by questioning the author's message and its hidden implications.

This approach is relevant to this study because, as stated by Shor (1999), a critical literacy class is a space where teachers invite students to move into deepening interrogations of knowledge in its global and local contexts. Moreover, the critical literacy perspective enables students to go beyond functionalism in reading and writing. As pointed out by Freire and Macedo (1987), "reading does not consist merely of decoding the written word or language; rather, it is preceded by and intertwined with knowledge of the world" (p. 29). 


\section{Argumentative competence: the art of producing and interpreting arguments}

Augustiniene and Čiučiulkienè (2012) define argumentative competence as "the set of knowledge, skills, attitudes and values which enables to prove the set thesis, to present clear, reliable, ethical, correct arguments to guarantee the successful construction of the information, its coding, decoding and interpretation" (p. 148). On the same line of thought, Freeley and Steinberg (2000) conceive argumentative competence as the use of language in specific communicative situations in which points of view, thoughts, beliefs, values, and actions are presented and justified in order to persuade or convince the reader or listener in a reasonable way.

The development of argumentative competence also involves interpreting argumentative discourse which, according to Van Eemeren and Houtlosse (2005), entails at least two cognitive processes: a categorizing process and an evaluative process. The categorizing process implies to label the argument and classify it into argumentative categories provided by the language the writer used (Plantin, 1995). Such categories may rely on general lexical items such as argument, to argue, on the one hand, or on designating a precise type of argument (e.g., analogy, appeal to authority, cause-effect, and deductive arguments), on the other. Once the argument has been identified and categorized, this may be characterized as acceptable or unacceptable by means of evaluation criteria, which are often left implicit because they may depend on the experience or background of the reader/evaluator.

These processes of categorizing and evaluating arguments are relevant to this study because, usually, students are taught to provide arguments but not to evaluate others' arguments or their own arguments. In short, people should become skilled arguers, by both producing and interpreting arguments. Hence, it becomes a challenge for the language teacher to redress the possible imbalance that may occur when learners are good at producing argumentation but not at interpreting argumentation, or vice versa.

\section{Argumentative essay writing}

Argumentative essay is "an essay in which you agree or disagree with an issue, using reasons to support your opinions" (Oshima \& Hogue, 2006, p. 142), taking a stand on a topic and using logic in order to convince readers (Kirszner \& Mandell, 2011).

As proposed by Oshima and Hogue (2006), an argumentative essay may include some key elements. The first element is to provide the reader with an explanation of the issue. The second is a clear thesis statement which states the specific topic of the essay. The third is a summary of the 
opposing arguments. The next is the rebuttal or refutation to the opposing arguments. The last element consists of the construction of the writer's own arguments. The writer has to make a decision about how to organize these elements within the essay.

In this research, argumentative essay writing is understood as a kind of essay in which the writer agrees or disagrees with an issue, taking a stand by using reasons, logic, and evidence to convince readers. From a critical approach, this kind of essay emerges when students engage in questioning their realities as there is a need or a problematic situation that encourages students to think on their own. In other words, as stated by Díaz (2002) the essay emerges when the author decides to offer an interpretation of a fact or situation and justifies the relation with other events.

\section{Research Design}

This study falls within the realms of qualitative action research, a type of investigation conducted by practitioners in the attempt to look for a change or improvement in their practices (Bell, 2005). This was exactly the case of this study as it aimed at improving the written argumentative competence of fourth semester pre-service teachers through a critical literacy approach. Burns (2003) also describes action research as a highly flexible research process where key cyclical moments take place. In this research, a dynamic cyclical process of planning, acting, observing, and reflecting was developed throughout the pedagogical intervention. Thus, this methodology provided the possibility to observe and ponder on the teaching practice, to promote a change through some actions, and to reflect upon the outcomes.

Participants, ten female and seven male students whose ages ranged between 15 and 20 years old, were enrolled in a seminar called "Oral and Written Expression in English" with an emphasis on written and oral argumentation. This seminar belongs to the BA program in Teaching English and Spanish at Universidad Pedagógica Nacional, a public institution in Bogotá, whose mission has to do with the training of teachers at all levels and modalities of education in Colombia.

In this action research, four data collection instruments were used. First, an initial questionnaire was helpful to create a participants' profile and to inquire about the students' background with reference to both argumentative competence and critical pedagogy, and a final questionnaire was used to close the research process, to ask about perceptions on the role of the activities and readings framed within the critical literacy approach. Second, three focus groups where conducted to reflect upon and close each one of the three cycles of the action research by having students interacting in a dialogical way. Third, audio recordings of class sessions 
to capture participant's interactions and their exact verbalization (Burns, 2003) were used. Finally artifacts were collected at different moments of the seminar development. These included three types of argumentative essays and the workshops designed and developed for each cycle of the instructional design.

\section{Instructional design}

The instructional design for this study was composed of one exploratory phase and three subsequent cycles where planning, acting, observing, and reflecting (Burns, 2005) were at the core. During the exploratory phase (three sessions) students were asked to write an argumentative paragraph with the purpose of identifying participants' prior knowledge on argumentative writing and analyzing the features that characterized their writing before the implementation. This piece of writing showed that there was a lack of sound foundations to support claims in an argumentative way. Students found it difficult to express a clear position as writers.

As a consequence, the first cycle, named "getting to know about argumentation," was intended to provide students with the chance to explore, analyze, and reflect upon essential concepts related to the argumentative competence before undertaking the writing process. These involved essential concepts such as argumentation, types of arguments, discourse devices and common fallacies in argumentative essay writing. This first cycle lasted nine sessions developed in about five weeks. The second cycle, "exploring multiple perspectives," aimed at helping participants with their argumentative essay writing process by writing a pros and cons essay. During this cycle, which took six sessions, student writers learnt how to plan and organize their essays taking into account given guidelines. The third cycle, named "taking a stand and proposing a solution," enabled student writers to be engaged in the process of writing an opinion and a problem solution essay. This cycle was developed over eight sessions. Students were encouraged to adopt a clear position regarding a controversial issue, propose a variety of solutions for a problem in their local or global context, and provide arguments to defend their views.

This instructional design was planned and developed as an "opportunity to create spaces for reflection, community support, networking, and freedom" (Chapetón, 2005, p. 21), as it was framed within a critical literacy approach. Thus, its aim was to foster sharing, dialogue, and transformation of traditional practices. With this critical approach in mind, during the development of each of the aforementioned cycles, participants were encouraged to explore previous knowledge and experiences so that value was given to their voices and background. This also implied giving students' voice to select the topics to be developed in their argumentative written 
practice. These topics were related to their most immediate concerns as pre-service language teachers (e.g., education, pedagogy, EFL teaching); as students of a public university (e.g., public resources and infrastructure); and as citizens of a big city like Bogotá (e.g., garbage management, pollution, and mobility in the city). They were also introduced to key concepts and theory in a dynamic way by asking questions and analyzing examples. The written practice was based on the use of critical literacy strategies (McLaughlin \& DeVoogd, 2004) such as questioning ${ }^{1}$ a text, analyzing a text, reading from a critical perspective, questioning the author, four corners (a critical literacy activity to express different points of view with regards to a statement or argument), meaning-making, question and problem posing.

\section{Findings}

Using the grounded approach for data analysis (Corbin \& Strauss, 1990), three categories emerged from the collected data. Table 1 depicts the emergent categories and sub-categories. These are subsequently explained and discussed.

Table 1. Categories resulting from the analysis

\begin{tabular}{|c|c|}
\hline Categories & Sub-categories \\
\hline Growing as argumentative writers & $\begin{array}{l}\text { - Student writers expressing } \\
\text { their position as writers } \\
\text { - Student writers strengthening } \\
\text { their positions as writers } \\
\text { - Student writers weighing their claims }\end{array}$ \\
\hline $\begin{array}{l}\text { Pre-service teachers building } \\
\text { their role as future teachers }\end{array}$ & $\begin{array}{l}\text { - Becoming aware of the role of educators } \\
\text { - Pre-service teachers profiling } \\
\text { themselves as future educators }\end{array}$ \\
\hline $\begin{array}{l}\text { Discovering transformation } \\
\text { tools to act upon the world }\end{array}$ & $\begin{array}{l}\text { - Teaching as a tool for change } \\
\text { - Calling to action on educational } \\
\text { and social issues }\end{array}$ \\
\hline
\end{tabular}

Source: Own elaboration.

\section{Growing as argumentative writers}

While engaged in writing activities with a critical literacy approach, the participants evidenced some transformations in the way they used to write argumentative texts. The analysis of data showed that the participants grew

1 Critical Literacy views readers as active participants in the reading process and invites them to move beyond passively accepting the text's message to question, examine, or dispute the power relations that exist between readers and authors. It focuses on issues of power and promotes reflection, transformation, and action (Freire, 2002). 
as argumentative essay writers particularly on three aspects: Expressing their position as writers, which allowed pre-service teachers to adopt a position with regards to an issue of their interest; strengthening their positions, which enabled them to back up their views by providing arguments, and counter-arguments; and weighing their claims, which is considered as the way each participant assessed their own statements to communicate personal judgments while taking into account the degree of assertion or emphasis in each claim.

\title{
Student writers expressing their positions as argumentative writers
}

This sub-category refers to the way in which participants were able to take a stand. The data showed that the participants tried to adopt a position that reflected their viewpoints through their written productions and oral interventions in class sessions avoiding neutral postures. Taking a stand is essential when developing argumentative competence (Van Eemeren \& Houtlouse, 2005). The following essays' extracts ${ }^{2}$ illustrate the way the participants expressed their personal views on a variety of issues:

\begin{abstract}
"In my view, some teachers believe that they practice an active education in the school, but the method is very traditionalist." (Pros-cons essay, S12, Nov. 5).

"In my opinion, learning to live in a democracy requires a gradual and progressive learning in which school years are central." (Opinion essay, S4, Nov.19).
\end{abstract}

The participants' statements show that they have a clear position regarding a specific topic. Participants' statements reflect that they do not express ambiguous standpoints and evidence the student writers' commitment towards their views when they state that it is their personal opinion and not what other people think. In fact, arguing constructively implies dealing with controversial issues in communicative situations, presenting positions and defending them (Infante, 1988). It is important to note that adopting a stance enabled participants to think by themselves and to voice their opinions and ideas, as shown below:

"I think that everybody has different talents or maybe one may have different cognitive faculties. Trying only one method could delay the processes of some students due to this." (Pros-cons essay, S13, Nov. 5).

2 The illustrative data samples are included verbatim. That is, in exactly the same words as used by the participants. 
The personalized form used to express positions by the subject pronoun I shows that the participants wanted to express their voices or be present in their texts. According to Coffey (2010), a way to empower students is by giving them opportunities to find their own voices. In this sense, critical literacy plays an important role in preparing citizens to participate in democracy. Thus, giving the students the chance to take a stand may prepare them to actively participate in the society by expressing their views freely growing in opposition to a culture of silence that is often promoted in the traditional classrooms.

\section{Student writers strengthening positions}

This sub-category refers to the way in which the participants made their positions stronger in order to convince the readers about the acceptability of their viewpoints. It is important to support the adopted positions because argumentation implies reason giving and its main objective has to do with justifying acts, beliefs, attitudes, and values (Freeley \& Steinberg, 2000). In this respect, the participants in this study supported their stances mainly in three ways: by providing different types of arguments (authority, analogy, cause-effect, and deductive), by providing arguments by example from their context and from other sources like statistics, and by providing rebuttals or counter-arguments. This is illustrated in the following samples:

"Each student has a unique outlook and therefore can present concepts and ideas in a different manner." (Wakeling, B.S.E.).

In other words, it is like paint on a pallet or crayons in a box to create a picture, each color adds more possibilities to the goal." (Authority Argument/Argument by analogy: Pros-cons essay, S16, Nov. 5).

"Food is the fuel that your body needs." (Argument by analogy: Workshop \#2, S9).

"Furthermore, if humans have flaws and teachers are humans, then teachers have flaws." (Deductive Argument: Opinion essay, S1, Nov. 19).

As Weston (2000) states, when students are asked to argue for their views on some issues, they often write elaborate statements, but they fail to provide strong support to consider their positions are appropriate. Argumentative competence requires elaborating supportive arguments that convince the reader (Nuñez \& Tellez, 2012). As seen in the samples above, when students provided different types of arguments or reasons in their argumentative essays, workshops, and during class activities, they were able to make their positions stronger in order to persuade the readers. 
Another way in which the participants supported their ideas was by providing examples from their context and from other sources, taking advantage of their experience or their knowledge of the world. Thus, the participants made connections between the issues discussed during the class sessions or in their written productions and the issues they knew from their background:

\footnotetext{
"For example, on February $7^{\text {th }}, 2003$ the FARC group attacked "El Nogal Club" which killed 36 people and wounded 200 more, after these facts it is hard for the thousands of people affected by this attack directly or indirectly, forgive and forget the damage that has been made." (Example from their local context: Opinion Essay, S13, Nov. 19).

"For example, [at UPN] deaf people had to study without an interpreter for almost 3 weeks, it was impossible for them to understand and the teachers were unable to help them." (Example from their immediate context: Problem solution essay, S2, Dec. 3).
}

The former excerpts illustrate how the participants were able to find examples from their reality and context, and from other sources. One of the participants mentions a terrorist attack that killed many people in his/ her city and another participant mentions the situation that handicapped students face at his/her university. In other words, the examples provided by student writers enabled them to make connections and support their positions. As individuals who are socially and historically constructed (Shor, 1999), participants confirmed that knowledge is not only produced in the heads of experts and that it is not possible for students to produce texts without taking into account their local or immediate context (Freire \& Macedo, 1987). Furthermore, providing examples is a type of argument used to support one's views or a generalization (Weston, 2000). In this respect, participants provided examples because they had the necessity to reinforce their positions with illustrations or specific cases related to the issues they had experienced or dealt with.

Another resource that participants used to back up their views was by providing statistical information. The participants found this strategy useful due to the fact that they supported their positions with numbers as the following samples indicate:

\footnotetext{
"According to the statistics mentioned above, currently $12.6 \%$ of the population is unemployed." (Opinion Essay, S16, Nov. 19).

"According with trading economics the Colombia's unemployment rate has decreased to 9.3 percent in August of 2013." (Workshop \#2, S16, Sept. 3).
} 
As shown here, student writers provided some statistics to back up their viewpoints. According to Oshima and Hogue (2006) opinions are not acceptable as support. They state that it is necessary to provide supporting details from outside sources-among these, statistics may be useful to support ideas and opinions in academic writing. The participants were aware that they needed more than their opinion to convince the readers and support their ideas.

Additionally, the participants in this study provided rebuttals or counter-arguments to weaken opposing views. In order to develop strong arguments, it is necessary to generate rebuttals anticipating opposing views that may emerge. The following samples reveal how the students responded to others' arguments to make theirs stronger:

"First of all, most of the institutions and the students believe that a native teacher improves the level of a foreign language in terms of pronunciation. However, I am agree with Arnsten who asserts that: Good English pronunciation does not mean using a British or American accent; if a teacher is Italian, an Italian accent is perfectly acceptable as long as the words are being pronounced correctly." (Opinion essay, S9, Nov. 19).

The participants used contrast connecting words such as however or but to add an opposing idea; that is, to provide a rebuttal in order to weaken other arguments. Oshima and Hogue (2006) emphasize providing rebuttals to the opposing arguments as one of the key elements in any argumentative essay because by refuting opposing views the writer can strengthen his/ her arguments even more. This process, in which the participants took into accounts the arguments of others and defended their own, highlights the social and interactive role of argumentation (Lappako, 2009; Van Eemeren \& Grootendors 2004; Ziegelmuller, Kay, \& Dause 1990) because writers engaged in a dialogue (Freire, 2002) where they take into account their audience or readers and respond to possible opposing arguments.

\section{Student writers weighing their claims}

Before writing any statement or argument, student writers examined them taking into account their audience or readers. Participants took advantage of discourse devices like expressions of modality such as, lexical verbs, modal verbs, adjectives, adverbs, and nouns (Salazar, 2008) in order to formulate different claims and indicate how committed they were to them. Participants used modality as a strategy to argue in a more academic way, and to consider the readers' views. As shown in the following quotes, the participants pondered about each statement to express their views in their essays and workshops: 
"Obviously, this can prove that traditional teachers believe that students do not possess knowledge and that is why they do not have the opportunity to speak and express their ideas." (Adverb, modal verb, and lexical verb: Opinion essay, S1, Nov. 19).

"I learnt many things when I revised Laura's essay. First, I had the possibility of learning of her mistakes. I learnt about punctuation and structure." (Noun: Workshop \# 23, S12).

The participants used these modality devices to attach expressions of belief and attitude to their statements. Also, the participants' statements demonstrate how they assessed reality through their propositions. The following excerpt illustrates how this student writer evaluates his own reality as a student at public university:

\begin{abstract}
"The riots have become one of the biggest problems for both teachers and students, these often produce an extensive damage, but the biggest drawback is the generated stoppage; which eventually shortens the time of all, making the teachers run with their academic program and leaving the students with the contents viewed over the top. Besides, they rarely, fail to meet its objectives but leave large losses. In my opinion it should be reconsidered through other less violent and more democratic forms where those who want to participate are free to do as those unwilling." (Adverbs, noun, modal verb: Workshop \#7, S7, Sept. 19).
\end{abstract}

As shown previously, the participant used modal devices not only to evaluate or read his reality (Freire \& Macedo, 1987) as a student at a public university where riots have some evident effects on academic processes, but also to express his position as a writer towards both their statements and his audience. This agrees with Salazar's (2008) definition of expressions of modality as devices used to express personal feelings, judgments, beliefs or knowledge regarding certain propositions. When looking at the participants' statements using modality devices, it is noticeable that they tried to communicate a particular vision of the world.

Apart from using modal devices, student writers laid emphasis on their claims through different degrees of assertion. This refers to the way participants attached a degree of certitude and emphasis to a thesis or statement. This degree of confidence in their assertions denotes a commitment to their propositions and a particular way to address the readers as shown in these excerpts:

"Currently, penalties for people who commit crimes against woman are really indignant" (Problem solution essay, S20, Dec. 3).

"We are not equal, each one is unique and we have the right to express ourselves and decide." (Workshop\# 10, S16, Oct. 3). 
"Schools need to change the way to teach English, breaking the traditional methods." (Workshop\# 6, S9, Sept. 17).

When students used words like has to, need to, and affirmative or negative statements like are really, are not, they are expressing a high degree of certainty or emphasis in order to convince the readers. Most of the claims with a high degree of certitude were controversial and reflected the writer's position on an issue. This orientation is related to what Pullman (2013) defines as a "debatable assertion" which is followed by a reason to believe the statement is true. In some of the affirmations participants provided reasons, and in others they finished their essays with a strong statement to catch the readers' attention or to make them think or reflect on a particular issue:

"Our country cannot forget the pain of so many bullets." (Opinion essay, S13, Nov. 1).

"Consequently, environmental education must give a sense of responsibility among people." (Problem solution essay, S9, Dec. 3).

These affirmative or negative statements where the student writers were pretty sure about their opinions denote certain commitment towards their statements. By putting emphasis on their propositions, the participants intended to communicate their personal views or feelings to the readers. This orientation is related to the two pragmatic functions of modal expressions highlighted by Salazar (2008). First, the writer's assessment of their assertions and the degree of confidence in those claims, second, how writers express compliance and modesty to their readers. In this sense, apart from expressing their views, it seems that the participants wanted to have an impact on the readers' perspectives.

\section{Pre-service teachers building their role as future educators}

It was found that the writing activities with a critical literacy approach had an impact on pre-service teachers regarding their future role as educators. Throughout the study, they took a stand and defended their positions with regards to their role as pre-service teachers and to the role of educators in general. The analysis of data showed that, apart from learning about the different tools used in argumentative essays, the participants revealed a great concern about a possible future role as in-service language teachers. 
It was observed that the impact that the writing activities with a critical literacy approach had on participants raised their awareness of the role of teachers and allowed them to profile themselves as future educators.

\section{Becoming aware of the role of teachers}

Looking at the participant's written production, it was possible to find that participants highlighted the role a teacher should play and they emphasized on some challenges teachers may face in their practice. The following excerpts indicate how participants understand the role of educators:

"Therefore the teacher must challenge himself to worry about the meaning of their vocation, which is none than to rediscover, to observe, to abstract and to build knowledge from the interests of their learners." (Problem solution essay, S16, Dec. 3).

"I believe that this is one of the most important activities that teachers need to do when they are working because kids need to be guided to be critical." (Workshop \# 3, S1, Sept. 5).

As shown in these pre-service teachers' statements, the participants perceive that teachers should challenge themselves, guide their students to build their own knowledge taking into account their voices or perspectives, accepting students' differences and skills, and helping them in order to become critical individuals. Something striking found in the data was that the participants attached more importance to the students' active role, perspectives, and interests than to the role of the teacher as an authority. In addition, being engaged in the activities with a critical literacy approach enabled participants to build some awareness of what implies to be a teacher. This relates to the Freire's notion that teachers should be learners and learners should be teachers. In other words, a classroom that acknowledges the critical literacy approach should also challenge traditional hierarchical relationships between the students and teacher (Coffey, 2010).

Another way to reflect upon the teachers' role was emphasizing some challenges educators face in their practice. Participants identified some challenges in terms of dealing with problems in the classroom, knowledge about the students' context and skills, and raising awareness of some issues, as shown below:

\footnotetext{
"As a future teacher I view that the higher education [public] is limited and a decline in resources, this affects the development of our society and leads to lack of education that grows daily." (Workshop \# 4, S13, Sept. 10).

"An Educator faces a general disinterest of students in the education, promoted by social paradigms" (Workshop \#20 S16, Nov.19).
} 
The students' extracts illustrate their awareness of the fact that teachers may face a variety of challenges in the classroom. In their statements, the participants show that the challenges go far beyond teaching a subject. Teachers are supposed to understand the situation of public institutions and deal with the students' passivity or disinterest. Pre-service teachers emphasized these challenges implying that more than one knowledge or skill is needed to face each challenge. This can be associated with the types of knowledge a teacher should have: content knowledge, pedagogical knowledge, curriculum and materials knowledge, knowledge about second language acquisition (SLA), knowledge about learners, and knowledge about context (Mann, 2005). Becoming aware of the challenges teachers may face in their practice could be a positive impact on pre-service teacher's future role as educators because they may start preparing themselves to overcome those challenges and others that may emerge from now on.

\section{Pre-service teachers profiling themselves as future educators}

Looking at the participants' statements through their written productions, it is possible to see how they tried to build a role as future educators they still do not have. In other words, they visualized themselves as teachers. Also, being engaged in the activities with a critical literacy approach enabled participants to raise some awareness about what it takes to become a language teacher. Throughout this study, the participants mainly focused on being aware that they need to be well prepared or qualified to confront their new role as in-service teachers in general and reflect upon the specific actions they need to take when assuming that role. These actions included promoting equality, knowing the students' context, and giving students the chance to reflect upon their reality. The following samples illustrate how the participants began to profile themselves as teachers in general:

\footnotetext{
"As a woman and future teacher, it came to my mind the necessity of having an education in which girls and boys are as one, equal beings that share and live in peace" (Pros and Cons essay, S2, Nov. 5).

"As a future educator, I believe that adolescents might be the future of our nation. As Freire asserts: "they need to go beyond the word in order for them to explore the world" through the reality to be aware about what is affecting not only them also everybody." (Workshop \# 5, S9, Sept. 28).
}

When participants refer to the importance of promoting equality from the classroom, knowing their students' context to teach them in an appropriate way, and going beyond the functionalism in reading and writing in order to explore the world, they are reflecting upon the teachers' practice. Freire and Macedo (1987) point out that "critical pedagogy would have to 
stimulate students to reflect" (p. 51). Thus, when the participants reflected upon their role as future educators they may have linked this reflection to their practices in the future. Additionally, it was interesting to find that some participants reached some awareness towards the complexity of teaching, as Bullough (2000) assures, many beginning teachers enroll in teaching programs relying too much on their abilities to teach, but without a real judgment of what it takes to teach or to be a teacher. In their statements, pre-service teachers seem to be aware that they need to do more than reading about pedagogy or academic qualifications because they will probably face other situations in the classroom. The following piece of evidence shows how some of the participants became aware of the complexity of teaching that goes beyond academic qualifications or pedagogical knowledge:

"However, it may be a problem in the future because some students think that it is easy to teach while the reality it is much harder when they try because one can read a lot about pedagogy, but putting into practice is a different step that needs a lot of vocation that some people do not have." (Problem solution essay, S13, Dec. 3).

When the participant mentioned that there is a gap between the theory of pedagogy and the teaching practice, she is conscious that pedagogical knowledge may be necessary, but not enough to handle some situations in a real educational context. In this sense, the participant has a new outlook on what it means to be a teacher. As the following excerpt illustrates, the participants also profiled themselves as future foreign language educators by reflecting upon the issue of being a non-native speaker of the language:

\section{"Are native teachers the only ones trained to teach English as a Foreign} Language EFt? (...)" (Opinion essay, S9, Nov. 19).

This pre-service teacher is questioning herself on her role as a future foreign language teacher in two ways. First, she questions the status of native English teachers as the only ones who can teach a foreign language properly. Second, she questions herself as a pre-service teacher as well as a non-native English teacher regarding the training she and non-native EFL teachers should have. Concerning this, Llurda and Moussu (2011) claim that linguistic theory has traditionally considered native speakers (NSs) as the only reliable source of linguistic data. However, these authors refute the myth of the native speaker as the ideal language teacher, arguing that this myth has been deconstructed through showing the lack of substantial evidence behind such a concept. They also denounce the "linguistic imperialism" or the "native speaker fallacy," which refer to the belief that the ideal teacher is a native one. 
Demystifying this false belief is important because the concept of the native English teacher promotes discrimination against non-native English teachers. In addition, Llurda and Moussu (2011) assert that non-native as well as native teachers need preparation to become better teachers. To mention just one aspect in terms of preparation, these authors point out that, although it is imperative for non-native teachers to acquire a good knowledge of the foreign language, it is equally essential for native teachers to gain a good knowledge of contrastive linguistics before being qualified to teach their own language.

Other examples of how pre-service teachers profiled themselves as foreign language teachers has to do with reflecting upon some students' needs which they have identified in the EFL context. The participants question issues such as making the language they teach useful and meaningful for students, serving as a bridge between the foreign language and the students, and taking into account the students' voices to choose materials according to their interests while promoting love for reading as well as dialogue, as illustrated below:

"In addition to this, the teacher might be a bridge between students and the English language." (Opinion essay, S9, Nov. 19).

"For example giving to students the opportunity of choose the kind of books they want to read taking into account the topics they like to read, because world literature is very good but some people dislike about they probably feel obligate to read it." (Workshop \# 13, S20, Oct. 15 $5^{\text {th }}$ )

Regarding this, Shor and Freire (1987) point out that teachers should work to have some good classroom experiences in reading texts. They accentuate the importance of reading texts as another way of reading the world. Furthermore, the participants talked from their experience as foreign language learners in order to visualize what they would do as language teachers. In this respect, Shor (1999) claims that reflection on experience could yield extensive theory, whereas theory alone is a mere verbal formula that obscures critical thinking. This also relates to the concept of becoming a teacher as an idiosyncratic process (Bullough, 1992) where past experiences, personality, and context influence the decisions that pre-service teachers make as they attempt to establish their role as EFL teachers. In this perspective, the participants' context as BA students, the problems and needs they have noticed in the past or present, enabled them to imagine the kind of educator they would like to be in the future. In this respect, Freire and Macedo (1987) assert that knowledge from experience is the starting point to create more accurate knowledge on the part of the people. 


\section{Discovering transformation tools to act upon the world}

The argumentative writing activities with a critical literacy approach also had an impact on pre-service teachers as active writers who discovered tools to act upon the world. The participants had opportunities to reflect on their willingness to act upon the reality around them as future teachers. This is important because it relates to the concepts of critical agency as self-conscious positions of questioning the ways things are, and imagining alternative arrangements for the self and for society (Shor, 1999). It was observed that the impact that the writing activities with a critical literacy approach had on the participants fostering this desire of transformation was essentially in two aspects: identifying teaching as a tool for change and calling to action on educational and social issues.

\section{Teaching as a tool for change}

The analysis of data has shown that pre-service teachers exalted the work of teachers as agents of change. The desire for changing their reality from the classroom is a big impact on pre-service teachers because a critical literacy approach involves achieving a possible transformation. The following samples reveal how participants see the work of teachers as a transformative force. The_first excerpt highlights the role of teachers against discrimination and the detriment conditions some people face daily. The second one emphasizes how teachers have the chance to promote a possible change in their students and, in turn, in their contexts:

\footnotetext{
"But I think that the main point of being a teacher is the desire of changing the system and the way that things have been for some people, I think that we want to help as many people as possible and that we are fighting against discrimination and bad conditions." (Problem solution essay, S2, Dec. 3).

"As I already said, is very important to create a critical thinking in the students, because for me (even sounds like a cliché) been a teacher is an opportunity to change the world."(Workshop \# 3, S6, Sept. 5).
}

As these pieces of evidence show, teachers are seen as transformative intellectuals who have to struggle against unfair or discriminatory conditions giving their students the possibility to express their ideas and, at the same time, through their practice, they can change the world or reality. In this respect, Coffey (2010) states that there is often an activist component to critical literacy education, where the teacher serves as the facilitator of social change. In this perspective, teachers are seen as agents of change and not as narrating subjects of knowledge (Freire, 2002). In addition, 
Shor and Freire (1987) claim that a liberating educator should be aware that transformation is not only a matter of methods and techniques. In this respect, pre-service teachers point out that teachers have the responsibility to contribute to the transformation of society.

Another way in which participants considered teaching as a tool for change was changing students' perspectives in order to transform reality. Participants highlighted the fact that one of the most important missions of teachers has to do with helping students to become active agents of change. The following extracts illustrate this claim:

"The role of the teacher as a guide in the building of knowledge involves the desire to transform subordinate, passive, and dependent students of traditional schooling, into independent, engaged, and active participants of the construction of their own knowledge." (Pros-cons essay, S16, Nov. 5).

"...it is an approach that may benefit students because the students can transform the society with their ideas, they can't be passive actors. They can examine their reality and to be democratic people. Also, they can make reflections about their problems." (Workshop \# 9, S12, Sept. 26).

Looking at the participants' written production and interventions in class sessions, it was possible to find that the role of a teacher as a guide involves turning passive students into active ones, engaged in the construction of their knowledge, students who are able to reflect upon their problems and read their world. Additionally, teachers should raise awareness among students about the transformation of reality. Kretovics (1985) asserts that, apart from teaching functional skills, teachers should provide students with the necessary conceptual tools to critique and engage society along with their problems or unfair situations. In the same line of thought, Chapetón (2007) states that the responsibility of an EFL teacher goes far beyond the instructional tasks and teaching students the components of the language. She affirms that students' critical, living connections with the sociocultural and political arena of their realities cannot be disregarded in education. In this perspective, participants highlighted the importance of examining their reality and reflecting upon real problems in order to transform the world.

\section{Calling to action on educational and social issues}

Data revealed the participants' interest in encouraging other students or people in general to take some actions regarding problems in their immediate context. Firstly, pre-service teachers called to action with regards to educational problems that affect them directly and proposed some solutions: 
"We should ask for better conditions and repairmen of the University, because it is like our home and we deserve spaces for everybody."(Problem solution essay, S2, Dec. 3).

"Projects can be carried out to introduce the practicum from the first semester considering that we are in the "Universidad Pedagogica" which is known for good training as future teachers. We are not required to begin to teach from the first semester, but at least to have more contact with teaching not only with books." (Workshop \#22, S13, Nov. 26).

As shown previously in the participants' reading of their world, they seem to show willingness to act upon their immediate reality when they say "we should ask" and "projects can be carried out." In other words, they recognize the possibility they have for human agency (Giroux, 1987). The participants have become active questioners of their reality regarding the facilities of the university. The last participant questions the curriculum organization and the Language Department decisions because she is aware that reading theory or books is not enough to teach. In fact, she highlights the need to have more contact with the educational setting from the beginning of the program bearing in mind the complexity of teaching the language. According to Coffey (2010) moving students to take some actions is also a characteristic of critical literacy. In this context, students may first encourage other students to act upon their reality and then they may get engaged in projects to improve the conditions of their community.

In addition, pre-service teachers also provided some solutions for particular problems in their immediate context. Apart from identifying difficult situations, participants proposed alternative options to solve the problems they usually face as BA students at a public university. Pre-service teachers identified problems such as the lack of green areas at "Universidad Pedagógica Nacional" (UPN) and the need to include pedagogy elective courses in the curriculum. The following samples reveal how they looked for alternative options to those problems:

"A possible solution is to educate all university community about the importance of green areas in order to raise awareness." (Problem solution essay, S3, Dec. 3).

"Universidad Pedagogica Nacional must include two more pedagogy hours as elective classes. As long as students have made a group for requesting a change in the curriculum, they could give a proposal that is to have two more pedagogy." (Workshop \# 22, S1, Nov. 26).

Through their written productions, participants had a space to propose solutions to problems as a previous step to act and change their reality. Regarding this, Shor (1999) claims that "the more space open or won for critical action, the more we can speak and act critically to change 
ourselves and the world" (p. 12). In other words, the author affirms that, while engaged in a critical reading of the reality, we can imagine alternative options, make plans, and evaluate or adjust our actions. This seems to be what participants attempted to do by identifying and proposing different possibilities to solve problems within their own lives as pre-service teachers.

Another way participants discovered transformation tools to act upon the world was by encouraging citizens or people in general to take actions on social problems as well as proposing solutions to them. The data showed that pre-service teachers were also concerned about problems that affect the society in general such as garbage management and child labor among others. In this regard, Coffey (2010) emphasizes the importance of using literacy as a vehicle for social change. The following quotes evidence how pre-service teachers suggested taking actions on social problems and provided their own solutions to them:

"Another solution to the garbage problem would be environmental education. EPA (Environmental Protection Agency) asserts that environmental education increases public awareness and knowledge about environmental issues or problems." (Providing a solution for garbage management: (Workshop \#22, S9, Nov. 26).

"One solution for child labor is to impose sanctions against the business where the child is working." (Problem solution essay, S12, Dec. 3).

Looking at the pre-service teachers' written productions, it is evident that they intended to raise awareness about those social problems and propose some concrete solutions. As put by Shor (1999), "critical education cannot feed the hungry or raise the minimum wage; it can only invite people into action to achieve these and other humane goals" ( $p$. 4). In this perspective, the writing activities enabled pre-service teachers to invite people to act in order to improve the conditions for everyone. Shor (1999) argues that human beings are certainly active when writing and highlights the act of writing as a form of social action. Regarding this, when participants proposed solutions to social problems, they developed some kind of agency in which they know that they can act upon the world in order to transform it.

\section{Conclusions}

This paper has discussed the impact that the implementation of argumentative writing activities with a critical literacy approach has had on the development of argumentative competence of a group of fourth semester pre-service teachers from a BA program in ELT. First, in their growing process as student writers, participants were able to make use of different tools and 
strategies that helped them state their positions by adopting a clear stance showing commitment towards their claims while expressing their voices in their texts. Thus, student-writers were able to strengthen their positions supporting them with different types of arguments, their knowledge of the world, and examples from their context as well as from different sources while making connections with their reality. They were also able to weaken opposing views by providing rebuttals or counter arguments stressing on the social interactive and dialogical role of the argumentative competence; weigh their claims and the degree of confidence they attached to them; and draw upon discourse devices such as modality devices to argue in a more academic way while evaluating the reality through their statements. Apart from this, student-writers laid emphasis on their claims through different degrees of assertion that aided them to express a degree of certainty or confidence in their statements and to address the readers in a particular way.

The critical literacy approach also had influence on the participants' building process of their role as future educators in two aspects. First, it fostered awareness among pre-service teachers on the role of any educator while emphasizing on some challenges they might face in their future as in-service teachers. Second, pre-service teachers tried to visualize themselves as educators assuming a critical role that would be different from the traditional practices they have experienced as students. Moreover, being engaged in the writing activities with a critical literacy approach fostered reflection that aided participants to raise some awareness regarding what it takes to become a non-native language teacher. There was also reflection on the actions participants need to promote when they become language teachers. These involve having the possibility to identify their own students' needs and interests to make them part of their practice in the EFL context. This calls attention, for instance, on Vargas Franco's (2015) assertion about the importance of adopting critical literacy approaches that respond to the contemporary needs and interests of a growing digitally mediated society.

A third important contribution of this study relates to the possibility of empowering pre-service teachers to discover transformation tools to act upon the world. First, the critical approach helped participants to discover that they may promote a transformation from the classroom conceiving teaching as a tool for change. In this sense, pre-service teachers highlighted the work of educators as a transformative force emphasizing on helping students to become active agents of change by modifying their perspectives and giving students the opportunity to reflect upon real problems in order to transform the world. Also, participants encouraged other students, readers of their work, in their argumentative texts, to take some actions regarding educational problems that affect them directly and proposed solutions to overcome them thus developing some degree of agency in which they became aware of the fact that they may act upon the world in order to transform it. 


\section{References}

Augustiniene, A., \& Čiučiulkienè, N. (2012). Development of argumentation skills in IBT/L context: A complex case study of teacher professional development programme. Kaunas: Kaunas University of Technology.

Bell, J. (2005). Doing your research project. London: Open University Press.

Bullough, R. Jr. (1992). Beginning teacher curriculum decision making. Personal teaching metaphors and teaching education. Teacher and Teaching Education, 8(3), 239-252.

Bullough, R. Jr, (2000). Convertirse en profesor: la persona y la localización social de la formación del profesorado. In B. Biddle, T. Good, \& I. Goodson (Eds.), La enseñanza y los profesores. I. La profesión de enseñar (pp. 99-165). Barcelona: MEC-Paidós.

Burns, A. (2003). Collaborative action research for English language teachers (3rd Ed.). Cambridge, UK: Cambridge University Press.

Chapetón, C. M. (2005). Creating reading clubs that foster resiliency: Theoretical foundations. Folios, 21(1), 3-16.

Chapetón, C. M. (2007). Literacy as a resource to build resiliency. Bogotá: Universidad Pedagógica Nacional.

Corbin, J., \& Strauss, A. (1990). Basics of qualitative research. Grounded theory procedures and techniques. London, UK: Sage.

Coffey, H. (2010). Critical literacy. Journal of Adolescent and Adult Literacy, 87.

Díaz, A. (2002). La argumentación escrita. Medellín: Universidad de Antioquia.

Freely, A., \& Steinberg, D. (2000). Argumentation and debate: Critical thinking for reasoned decision making. Belmont/Wadsworth: Thomson Learning.

Freire, P. (2002). Pedagogy of the oppressed. New York, NY: Continuum.

Freire, P., \& Macedo, D. (1987). Reading the word and the world. Westport: Bergin \& Garvey.

Giroux, H. (1987). Literacy and the pedagogy of Political Empowerment. In P. Freire, \& D. Macedo, Literacy Reading the Word and the World. (pp. 1-28) Westport: Bergin \& Garvey.

Green, P. (2001). Critical literacy revisited. In H. Fehring, \& P. Green (Eds.), Critical literacy: A collection of articles from the Australian Literacy Educators Association (pp. 15-39). Newark: International Reading Association.

Infante, D. (1988). Arguing constructively. Prospect Heights, IL: Waveland Press Inc. 
Kirszner, L., \& Mandel, S. (2011). The brief Wadsworth handbook. New York, NY: Wadsworth.

Kretovics, J. (1985). Critical literacy: Challenging the assumptions of mainstream educational theory. New York, NY: McGraw Hill Education.

Lapakko, D. (2009). Critical thinking in action. Bloomington, IN: Universe Books.

Llurda, E., \& Moussu, L. (2011). Non-native English-speaking English language teachers: History and research. Cambridge Journals, 41(3), 315-348.

Mann, S. (2005). The language teacher's development. Language Teaching, 38, 103-118.

McLaughlin, M., \& DeVoogd, G. (2004). Critical literacy enhancing students' comprehension of text. New York, NY: Scholastic.

Nuñez, A., \& Tellez, M. (2012). Using debates in the classroom: A pedagogical strategy for the development of the argumentative competence in the teaching of English as a foreign language. Bogotá: Universidad Externado de Colombia.

Oshima, A., \& Hogue, A. (2006). Academic writing. New York, NY: Pearson.

Plantin, C. (1995). L'argument du paralogisme. Paris: Hermes.

Pullman, G. (2013). Persuasion, history, theory, practice. Indianapolis, IN: Hackett Publishing Company Inc.

Salazar, D. (2008). Modality in student argumentative writing: A corpus-based comparative study of American, Filipino and Spanish novice writers (Unpublished doctoral thesis). University of Barcelona, Barcelona, Spain.

Shor, I. (1999). What is critical literacy? Journal of Pedagogy, Pluralism and Practice, 1(4), 1-32.

Shor, I., \& Freire, P. (1987). A pedagogy for liberation. Dialogues on transforming education. Westport, CT: Bergin \& Garvey.

Van Eemeren, F., \& Houtlosser, P. (2005). Argumentation in practice. Amsterdam: John Benjamins.

Van Eemeren, F., \& Grootendorst, R. (2004). A systematic theory of argumentation. Cambridge: Cambridge University Press.

Vargas Franco, A. (2015). Literacidad crítica y literacidades digitales: ¿una relación necesaria? Folios, 42(2), 139-160.

Weston, A. (2000). A rulebook for arguments. Indianapolis, IN: Hackett Publishing Company.

Ziegelmueller, G., Kay, J., \& Dause, C. (1990). Argumentation: Inquiry and advocacy. Englewood Cliffs, NJ: Prentice Hall. 
